\title{
FITTED SHARIA IN DEMOCRATIZING INDONESIA
}

\author{
Hakimul Ikhwan \\ Gadjah Mada University, Yogyakarta - Indonesia | hakimul_ikhwan@yahoo.com
}

\begin{abstract}
This article argues that the so-called shariainspired regulations have been locally fitted through democratic processes that engaged together the elected legislative body and the executive office as well as various social groups. It bases on a qualitative fieldwork in Cianjur, a district in West Java Indonesia. There are three underpinning factors to the fitted sharia. First, it is possible because the discursive elements of sharia that enabled the Islamists to find a local and perhaps diluted, and more moderate formulation of sharia. Second, social diversity with no single group predominating required compromise and political alliance within and between the Islamist and non-Islamist groups. Third, the so-called sharia has number of secular functions related to politics, economy, and local custom that eventually brought the contesting groups to compromise. Thus, the resurgence of the sharia-inspired regulation is driven by various factors ranging from religiosity and piety to the practical and pragmatic reasons.
\end{abstract}

Keywords: Sharia, Democracy, Islamism.

\section{Introduction}

The development of democracy has eventually brought Indonesia as the only country considered 'free' in Southeast Asia. ${ }^{1}$ The UK Guardian used the term "miracle" to describe the development of democracy in Indonesia in the post-Suharto era. ${ }^{2}$ However, in recent years, many observers have showed defects and shortcomings of

\footnotetext{
${ }^{1}$ Freedom House, "Indonesia," Freedom in the World, 2013, http://www.freedomhouse.org/report/freedom-world/2013/indonesia.

2 Kishore Mahbubani, "Kishore Mahbubani: Indonesia's Democratic Miracle," the Guardian, September 19, 2008, http://www.theguardian.com/commentisfree/2008/sep/19/indonesia.terrorism.
} 
Indonesian democracy. Aspinall and Mietzner states it still far from ideal. It still has structural problems, especially corruption and weak law enforcement. ${ }^{3}$ Freedman and Tiburzi add three more problems of Indonesian democracy; military abuses, protection of minorities and Islamic radicalism. ${ }^{4}$ In commemorating twenty years of post-Suharto's democracy, several media highlighted the retreat or set back of Indonesian democracy. ${ }^{5}$ Among the issue is the position of Islam as religion of the majority play in this democratic arrangement. ${ }^{6}$

As a country with Muslim majority population, the question between Islam and democracy is always on the table with mixed answers. ${ }^{7}$ One of the answers has been the the issuance of shariarelated regulations. Between the year 1999-2012, somewhere between seventy-eight and 160 sharia-related regulations or bylaws are approved and enacted in many regents and municipalities across Indonesia. ${ }^{8}$ The persistence of development of democracy along with the growth of shariatization ${ }^{9}$ would put into question some dominant contemporary

${ }^{3}$ Edward Aspinal and Marcus Mietzner (eds), Problems of Democratization in Indonesia: Elections, Institutions and Society (Singapore: Institute of Southeast Asian Studies, 2010), p. 2

${ }^{4}$ Amy Frredman and Robert Tiburzi, "Progress and caution: Indonesia’s Democracy", Asian Affairs: An America Review, vol 39 (2012), p. 131.

${ }^{5}$ See for instance, Editorial Notes, Indonesian democracy in Retreat: The Jakarta Post', The Strait Times, 5 of February 2018, https://www.straitstimes.com/asia/seasia/indonesian-democracy-in-retreat-the-jakarta-post and Krithika varagur, '20 Years on, Indonesia Considers Legacy of Its 'Reformation', voice of America, 23 of May 2018, https://www.voanews.com/a/years-on-indonesia-considers-legacy-of-its-reformation-/4406183.html

${ }^{6}$ For short review of this topic, please refer to Masdar Hilmy, Islamism and Democracy in Indonesia: Piety and Pragmatism, (Singapore: ISEAS - Yusof Ishak Institute, 2010).

7 Thomas B. Pepinski, "Measuring piety in Indonesia", paper presented at the 2016 AALIMS Conference on the Political Economy of Islam and Muslim Societies (2016), pp. 32-33.

8 Robin Bush, "Regional Sharia Regulations in Indonesia: Anomaly of Symptom?," in Expressing Islam: Religious Life and Politics in Indonesia, 2008, 176; Michael Buehler, "Subnational Islamization through Secular Parties: Comparing Shari'a Politics in Two Indonesian Provinces," Comparative Politics 46, no. 1 (October 1, 2013): 67, https://doi.org/10.5129/001041513807709347.

${ }^{9}$ The term shariatization was first employed by Olivier Roy in his book the Failure of Political Islam (Cambridge, Massachusetts: Cambridge University Press, 1994). In Indonesian context this term is used by M. Nur Ikhwan in his article entitled "The Politics of Shariatization: Central Governmental and Regional Discourses of Shari'a Implementation in Aceh", in Michael Feener and Mark Cammack (eds), Islamic Law in 
discourses on their incompatibility. ${ }^{10}$ Also, it raises the question of how and why did Indonesian Islamists adjust their ideologies to fit with democratic processes and how has the democratic process adapted to Islamist involvement in post-Suharto Indonesian politics?

To address the question, the article employed a qualitative fieldwork in the West Javanese District of Cianjur Indonesia. Cianjur is a front-liner of initiation of sharia-oriented regulations at the local level in post-Suharto's Indonesia. It is also a home of notable Islamist vigilante group, i.e, Reformist Movement of Islam (GARIS - Gerakan Reformis Islam) which was established in 2001. With membership exceeding 28.000 people and cohesive mass movement, GARIS is an influential political player in Cianjur. It can exert substantial political pressure in one way or another because of its direct link with Darul Islam (DI) rebellion of the 1950s in which Cianjur is one of its stronghold. ${ }^{11}$ GARIS has three main programs which show intolerance, namely their review of draft of national penal code, opposition to Christian mission, and opposition to Ahmadiyah. ${ }^{12}$ Historically, Cianjur is one of the major bases for Darul Islam (DI), an Islamist rebellion in the 1950s that fought for the establishment of an Islamic state in Indonesia as well as basis for Masjumi party, (Majlis Sjuro Muslimin Indonesia - Consultative Council of Indonesian Muslims), one of Indonesia's main political parties during the period of parliamentary democracy in the 1950s-60s with Islamist persuasion. Finally, Cianjur is known as Kota Santri (city of pious Muslims) with about 99 percent Muslim population of the total three million

Contemporary Indonesia: Ideas and Institutions (Boston: Islamic Legal Studies Program, Harvard University Press, 2007), pp. 193-215

${ }^{10}$ See, for instance, Samuel P. Huntington, The Clash of Civilizations and the Remaking of World Order, Simon \& Schuster pbk. ed (New York: Simon \& Schuster Paperbacks, 1993); Samuel P. Huntington, The Third Wave: Democratization in the Late 20th Century (USA: University of Oklahoma Press, 1991); Bernard Lewis, The Crisis of Islam: Holy War and Unboly Terror (New York: Random House Trade Paperbacks, 2004); Francis Fukuyama, The End of History and the Last Man (New York: Simon and Schuster, 1989); Francis Fukuyama, "The West Has Won," The Guardian, October 10, 2001, sec. World news, http://www.theguardian.com/world/2001/oct/11/afghanistan.terrorism30.

${ }^{11}$ Michael Buehler, The Politics of Shari'a: Islamist Activists and the State in Democratizing Indonesia (Cambridge: Cambridge University Press, 2016), p. 133

12 Ratno Lukito, "Islamisation as Religious Intolerance: The Case of GARIS in Cianjur, West Java", Al-Jami'ah: Journal of Islamic Studies, vol. 54, no. 2 (2016). 
inhabitants. ${ }^{13}$ The consequence is that aspiration to implement Islam, albeit in different gradations and strategies is apparent in Cianjur. That is why they are qualified to be considered as Islamists.

Considering such strong political Islam background, nearly all political parties, regardless their ideological platform, show their commitment to the implementation of sharia, albeit in different levels. In Cianjur, all major political parties are present. Interestingly, the so called nationalist parties such as PD, PDIP, Golkar, and later Nasdem get considerably more votes than the parties traditionally affiliated to Islam, such as PBB (Partai Bulan Bintang - Crescent and Star Party), PKB (Partai Kebangkitan Bangsa - National Awakening Party), PAN (Partai Amanat Nasional - National Mandate Party), and PKS (Partai Keadilan Sejahtera - Justice and Welfare Party). PBB, which is considered ideologically descendent of Masjumi, ceased to exist after 2005 regional election due to low votes. Thus, any effort by Islamists to implement sharia should calculate this political configuration.

The article is based on interview with 59 informants from different social groups representing government officers, researchers, political parties, youth organizations, and a few religious leaders of all acknowledged religions.

This article discusses the co-existence of democratization and sharia-related regulations in Cianjur. Such a co-existence is a result of adaptation amongst the Islamists to work within the democratic political system, and in turn, the democratic system has also adapted to the Islamists' aspiration of certain degree of sharia-related symbolism. It refutes essentialist views as represented by Huntington, ${ }^{14}$ Lewis, ${ }^{15}$ and Fukuyama ${ }^{16}$ who perceive Islam, including shariatization, as static entities with fixed characteristics. The case of Cianjur has indicated that the so-called sharia-related regulation is a form of 'locally repackaged sharia' that blends local custom and Islam-related symbolism. It has the effect of not only moderating sharia to become more open and inclusive but also silencing critical groups of the nationalist and secularist groups.

\footnotetext{
${ }_{13}$ Biro Pusat Statistik Cianjur, Kabupaten Cianjur dalam Angka 2017 (Cianjur: Biro Pusat Statistik Cianjur, 2017), p. 145

${ }^{14}$ Huntington, The Clash of Civilizations.

${ }^{15}$ Bernard Lewis, The Crisis of Islam (New York: Random House, 2004).

${ }^{16}$ Francis Fukuyama, “The end of history?", The National Interest (Summer 1989), pp. 1 18.
} 
In a pluralistic society like Indonesia, where identities in terms of religion, ethnicity, race, and parties are frequently contested, it is important and reasonable to develop a democratic system that, at the very least, pays attention to political rights and civil liberties, but which also cultivates the development of an open space of articulation to various opinions and interests in order that the nation is not ruled by the few. With this in mind, the argument in this article departs from post-structuralist's notion of democracy ${ }^{17}$ that frames democracy should maintain 'the social' as an open space and resist the kind of hegemonic closure characteristic of 'liberal' democracy. ${ }^{18}$ It should ensure the possibility of openness and the ultimately undecided moment of articulation, where different political groups reproduce commonly-bounded signification to establish coalescence. 19 Democracy, in a pluralistic society, is coloured by radical indetermination whereby it is impossible to have a single perspective or universal point of view. ${ }^{20}$ Mouffe ${ }^{21}$ proposed an 'agnostic pluralism' where politics should be to create unity in a context of conflict and diversity. Also, unlike Habermas' 22 deliberative democracy, which deemed that communicative reasons would bring consensus and thus eliminate conflict among different groups in democratic society, the post-structuralist model of democracy is of the view that disagreement between political groups is probably within a democratic society.

${ }^{17}$ Laclau and Mouffe, Hegemony and Socialist Strategy (London: Verso, 1985)

18 See Joseph A. Schumpeter, Capitalism, Socialism, and Democracy (Radford, VA : Wilder Publications Limited, 2012); Robert Alan Dahl, Polyarchy: Participation and Opposition (USA: Yale University Press, 1971); R Rose, "Democratic and Undemocratic States," in Democratization, ed. Christian Haerpfer et al. (Oxford: OUP Oxford, 2009); Richard S. Katz and Peter Mair, "Changing Models of Party Organization and Party Democracy The Emergence of the Cartel Party," Party Politics 1, no. 1 (January 1, 1995): 5-28, https://doi.org/10.1177/1354068895001001001; Dan Slater, Ordering Power: Contentious Politics and Authoritarian Leviathans in Southeast Asia (Cambridge: Cambridge University Press, 2010).

19 Ernesto Laclau, "Identity and Hegemony: The Role of Universality in the Constitution of Political Logics," in Contingency, Hegemony, Universality: Contemporary Dialogues on the Left, ed. Judith Butler, Ernesto Laclau, and Slavoj Žižek (Verso, 2000), p. 85.

${ }^{20}$ Mouffe, The Return of the Political, (London: Verso, 1993), p. 11.

${ }^{21}$ Mouffe, "Deliberative Democracy or Agonistic Pluralism?", Political Sciences Series 72, Institute of Advance Studies, Vienna (December 2000).

22 Jurgen Habermas, The Theory of Communicative Action: Reason and the Rationalization of Society (USA: Beacon Press, 1984). 
Disagreement and, indeed, opposition among groups are seen as part of democracy and democratic processes.

The presence of sharia symbolism, along with the development of democratization, is thus understood as the process where each contesting group will construct and draw upon symbolism, identities, and interests that are based on their assessment of the existent situation. In the Reformasi era, an era after the fall of Suharto regime in 1998, it is apparent that meaning and interpretation over symbolism and religious practices may shift when the configuration of actors also shifts. With this in mind, various expressions and forms of movements by Islamists do not necessarily have similar religious-piety orientations. More precisely, the driving force of Islamism has not always been driven by transcendental orientation. Similarly, in practical politics, democracy may also be used for different objectives and refer to various meanings as well as employing different instruments of mobilisation over time such as religion, ethnicity, and money. With respect to this, the resurgence of sharia-inspired regulation can be seen as taking part in a developing process of democratization in postSuharto.

How is the fitted sharia possible in Cianjur West Java? This article finds three underpinning factors that enable the fitted sharia. First, Cianjur Islamists' knowledge of sharia is open to multiple interpretations and practices that enables sharia to blends complex convergences of local cultural identities, political interest, and economic rationality in the increasingly contested political sphere in the newly developed democratization of post-Suharto Indonesia. Second, Cianjur is home to various civic associations and political groups with no single group predominating. Although the people of Cianjur is majority Muslims but they are affiliated to widely diverse religious and social organizations. Thus, those groups of difference have to negotiate with other over religious understanding and strategicideological form of movement to exercise political power and maintain control over the society in general. Third, the so-called sharia has number of secular functions related to politics, economy, and local custom and value. All these eventually helped to aid the non-Islamist groups to accept the usage of sharia symbolism in public. 


\section{The Locally Fitted Sharia}

This article has found that the so-called sharia and the movement of shariatization have shifted from one form to the other over different time period. The shift took shape at the interpretation and knowledge about sharia as well as at the form of application of sharia. Initially, in the immediate period of the Reformasi (1999-2000), sharia is seen as a 'God-prescription' in dealing with all human matters and which held ready-to-use 'formulas' to deal with not only religious and spiritual sphere but also social, political, economic, and cultural issues. ${ }^{23}$ As a result, in the early Reformasi era, especially in 1999 to 2006, the agenda of shariatization has mainly manifested in a formalistic form of sharia such as enforcing women head veil in the public life, daily recitation of the Quran, and congregation of mid-day prayers for the male Muslim civil servants.

This shift can be best described with the evolution of Gerbang Marhamah in Cianjur, West Java. ${ }^{24}$ Gerbang Marhamah is an acronym for Gerakan Pembangunan Masyarakat Berakblaq Al-Karimah - a Movement for development of religiously good behavior. ${ }^{25}$ It was a program to implement sharia in Cianjur which was set up in 2001 during the term of Wasidi Swastomo as the Regent of Cianjur. Bureaucrat by profession, Swastomo himself is not an islamist, but he made promise prior local election to islamists, especially with GARIS to implement sharia once elected as regent of Cianjur. Among the main agendas of Gerbang Marhamah during his tenure were conducting jama'ah (congressional) prayers in workplace, especially in government agencies, paying alms and charity, arranging religious gatherings and creating Islamic environment in government agencies. The regent also appointed many Penyuluh Akhlaqul Karimah (PAK instructor for good behavior) with the task of campaigning Gerbang Marhamah to Cianjur Muslim population.

${ }^{23}$ Bupati Cianjur, “Apa Dan Bagaimana Pelaksanaan Syari'at Islam Di Kabupaten Cianjur: Bahan Penyuluhan Dan Sosialisasi Bagi Para Petugas Akhlaqul Karimah (PAK) Di Kabupaten Cianjur," 2002; Lembaga Pengkajian \& Pengembangan Islam, "Format Dasar Pelaksanaan Syariat Islam Di Kabupaten Cianjur" (Cianjur: Lembaga Pengkajian \& Pengembangan Islam Kabupaten Cianjur, 2001).

24 Amin Mudzakkir, "Islam Priangan Pergulatan Identitas dan Politik Kekuasaan", Tashwirul Afkar, No. 26 (2008), pp. 78-81.

${ }^{25}$ Lembaga Pengkajian dan Pengembangan Islam (LPPI), Mewujudkan Masyarakat Cianjur Sugib MUkti Tur Islami: Sebuab Upaya melaksanakan Syariat Isalm di Kabupaten Cianjur (Cianjur: LPPI, 2001). 
Over shadowed by Islamists' attacks to Ahmadiyah community, Muslim leaders from various Islamic organizations such as Nahdlatul Ulama, Muhammadiyah, PUI (Persatuan Umat Islam - Muslim Union), Persis (Persatuan Islam - Islamic Unity) and MUI (Majelis Ulama Indonesia - Indonesian Council of Ulama) were behind Wasidi Swastomo to ensure his reelection as regent of Cianjur in the 2006 district direct election. However, although with this full endorsement and political backing of Golkar party and some Islamic parties of PBB, $\mathrm{PKB}$ and PAN, he was eventually defeated by a very narrow margin to Tjetjep Muchtar Soleh, another secular-nationalist bureaucrat backed by Partai Demokrat (PD - Democrat Party). ${ }^{26}$

The defeat of Swastomo, however, had also something to do with GARIS's withdrawal from supporting him, because of his decision to insistence nominate a party cadre as running mate at the expense of GARIS head of Cianjur, Anjep Hermawan. This resulted in GARIS launched smear campaign against him. ${ }^{27}$ Interestingly, soon after being elected, the new regent believes that supporting Gerbang Marhamah is politically strategic. He decided to continue Gerbang Marhamah in 2006 arguing that it is aspiration of Muslim population of Cianjur. There were 12 aspects of Gerbang Marhamah under this new regent, namely good behavior, ritual, bureaucracy, politics, education, dakwah (Islamic propagation), economy, social affairs, law, arts and culture.

The shift of sharia approach by employing popular programs after the defeat of political Islam is commonplace elsewhere in Indonesia. ${ }^{28}$ Thus, the case of Cianjur is not an exception. It is well adapted by islamists in the region. They believe that sharia is religiously more legitimate than democracy. Democracy is seen by the Islamists as merely a 'human creation' and thus not able to solve the problems they experience in the region. For instance, Harun, a senior figure of the Islamist Party of Partai Bulan Bintang (PBB), a small party which

\footnotetext{
${ }^{26}$ Tjetjep Mochtar Sholeh was defeated by Wasidi Swastomo in 2001's parliamentary election for district head with narrow margin of 22 to 21 votes. But in 2006, Wasidi was defeated by Tjetjep Mochtar Sholeh in district direct election also bu narrow margin of $43.37 \%$ to $43.08 \%$ Buehler, The Politics of Shari' a, p. 160 and p. 165.

${ }^{27}$ Buehler, The Politics of Shari $a$, p. 166

28 See for instance Moh. Nurhakim, "The New Orientation of Islamic Revivalist Movements in the Context of Post-Reform Indonesia", paper presented at $4^{\text {th }}$ International Conference the Community Development in ASEAN, Phnom Penh Cambodia (March 22 - 23, 2017), p. 496
} 
ideologically was inspired by Masjumi, said "I do not observe the majority opinion [through electoral democracy] but the truth [of Islam/Sharia], although it is minority. Being majority is not necessarily the truth." Wawan, a Local Chairman of Persatuan Umat Islam (PUI Muslims Union), another islamists organization, concurred "In early days of the Reformasi era, there were desires [among Islamists] to urge sharia as a solution for problems in law enforcement. Sharia would solve our problems."

However, after local election in 2006 with the defeat of the candidate supported by Islamist parties and many muslim leaders, the interpretation and implementation of sharia have shifted to another form. The Islamists turn around the interpretation of the essence of sharia from 'God prescription' to 'serving human and humanity.' As Thoha, the Head of PBB of Cianjur, told:

[In the past] we merely viewed Islam from the idealistic landscape that did not contribute in solving the problem of people's social and economic needs. It never addressed public issues such as economy and health. Therefore, we now deal with these issues seriously in our campaign.

The Islamists shift to promote programs channeled toward health service providers - hospitals and pharmacies - for people in need of medical treatment, especially those less privileged in remote areas and relatively less educated. Thoha further said:

We provided medical services (by opening occasional free medical services to public). We tried to deal with the issues that had not been touched in the past. It is not to leave the old [symbolic-ritualism of sharia] but we need to make it concrete in dealing with people's daily needs. This is to connect between the ideal and the real. In [the teaching of] Islam, the best people are the most useful to others. This principle should be advanced, not only in the health sector but also the rest including governance and bureaucracy.

In addition, the enactment of district regulation on zakat management in $2004^{29}$ marked this shift. In the view of the Islamists, the earlier sharia campaign had little implication in improving people's welfare and earnings. On the other hand, zakat is thus seen as a sharia-

${ }^{29}$ Arskal Salim, "The Islamisation of Regional Regulations and Its Impact on Good Governance in Contemporary Indonesia", in Tim Lindsey, Helen Pausacker (eds), Religion, Law and Intolerance in Indonesia (Abingdon and New York: Routledge, 2016), p. 325. 
compatible instrument that would improve financial situation of the poor. This zakat regulation signified a shift from the previous agenda heavily oriented towards the sacred to 'serve the God' to humanity issues.

Moreover, the experience in Cianjur indicated that sharia-related regulation had become a nodal point which brought the contesting groups of the Islamists and the nationalists to came to agree upon. In the case of the enactment of zakat regulation, despite their maintaining different interests, rationalities, and interpretations of the policy is this the proof. For the Islamists, besides theological orientation to behave in accordance to sharia, zakat also has a mundane-strategic orientation that serves to strengthen the Islamist groups' political existence in Cianjur. Meanwhile, in the view of the secular-nationalist establishment, accommodation of the zakat regulation helps shore up his power via religious channels, increasing his influence, popularity, and electability. Moreover, although this secular-nationalist Executive Head agreed on zakat enforcement, it had only been enacted and sustained through and within the local government institutional system.

\section{Underpinning Factors to the Fitted Sharia}

How is the fitted sharia possible in Cianjur post-Suharto Indonesia? There are three answers to the question. First, what happens in Cianjur has indicated that sharia is a form of 'discursive tradition' of Islam that blends complex convergences of local cultural identities, political interest, and economic rationality in the increasingly contested political sphere in the newly developed democratization of post-Suharto Indonesia. Second, Cianjur is home to various Islamic civic associations and political groups with no single group predominating. Although the people of Cianjur is majority Muslims but they are affiliated to widely diverse religious and social organizations with also various religious persuasion. Thus, those groups of difference have to negotiate each other over religious understanding and strategic-ideological form of movement to exercise political power and provide what the population needs in term of implementation of religion in general. Third, the so-called sharia has a number of secular functions related to local politics, economic interests, and local custom and value. All these factors eventually bring the Islamist and the secular-nationalist groups to compromise over the 
the usage of sharia symbolism in public. Further discussion on these three factors will be in the following subsections.

\section{Sharia as a Discursive Tradition of Islam}

This article argues that the fitted sharia in Cianjur is possible because the interpretation and knowledge of the so-called sharia are not a fixed and permanent but somewhat open and, indeed, negotiable that fluctuated in line with specific social and political contexts. It uses Asad's 30 conception of 'discursive tradition of Islam' as it enables accommodation of the multiplicity interpretation and application of Islam, including sharia. Asad's conception is useful in highlighting awareness about the reproduction of religious knowledge over different time periods among the Islamists. The knowledge reproduction can be a by-product of endogenous pressure as a result of intensive interaction among various groups within Islam, as well as resulting from exogenous factors following Islamists' engagement with the process of democratization. In other words, the sharia and shariatization have to be understood as open-ended discourse and contingent processes. They are neither a permanent nor fixed form of expression or interpretation of Islam. Thus, sharia has been framed as a phenomenon that emerges in the 'present,' is related to the 'past,' and oriented to the 'future.' It has linked to current religious practices and the contextual interpretations of the foundational texts of Islam. As Asad ${ }^{31}$ stated "Islam is neither a distinctive social structure nor an eclectic collection of beliefs, artifacts, customs, and morals. It is a tradition." Here, a tradition consists essentially of discourses related to a particular context that shaped a form of tradition and purpose of a given practice. Within this frame, religious interpretation and practices at the local level are not perceived as 'the less real' Islam-as in the orientalists' worldview ${ }^{32}$ - but rather are linked to the great tradition and transcendental dimension of Islam.

The arguments used by the Cianjur Islamists to account for the shift is that according to their interpretation of the Hadith - the second source of Islam — practicing good behavior or Budi Baik is the

\footnotetext{
30 Talal Asad, "The Idea of an Anthropology of Islam", Occasional Paper, Center for Contemporary Arab Studies (Washington DC: Georgetown University, 1986), p. 7.

${ }^{31}$ Ibid., p. 14.

32 Edward W. Said, Orientalism: Western Conceptions of the Orient (London: Routledge and Kegan Paul Ltd, 1978).
} 
primary goal of the prophethood of Muhammad. This is concluded from a hadith narrated by Bukhari and others which reported the Prophet Muhammad once said: "verily I (Muhammad) was sent to realize good behavior (of mankind)." 33 According some islamists in Cianjur, the main indicator of success in performing good behavior is observing sharia. They maintain that this hadith promote 'good behavior' while still remaining in line with the basic principles of sharia.

The Islamists argument above suggest that the shift in the form of interpretation and application of shariatization is not to suggest that sharia has lost its connection with the sacred texts - Qur'an, Hadith, and Islamic jurisprudence - and the traditions of Islam, but that these connections are subject to multiple reinterpretations. The shift has gained significance since the Cianjur's Islamists believe that the main cause of the Indonesian economic crisis of the late 1990s is rooted in the problem of crises in akblaq (morality), and thus the promotion of Akhlaq al-Karimah (noble morality or good behavior) would be the sole solution to the crises, as well as a way of preventing what they saw as the threats to local culture, morality, and values in the future ${ }^{34}$.

The shift in the forms of application of sharia from the 'formalistic' to the 'substantive' sharia indicates an increasing awareness of the necessity to articulate Islamic teachings and doctrines in dealing with welfare issues. The increasing awareness is, of course, not always driven by the spirit of religiosity and piousness for the sacred orientation, but is also shaped by pragmatic orientations related to contestation over political power and economic resources at the local level in Cianjur. This development illustrates that making Islam more immediately and explicitly beneficial to the betterment of human life does not necessarily mean that the promotion of Islamism-related identity and symbolism is abandoned.

Also, the discursive sharia has manifested in the fact that the manifestation of Sharia is incredibly diverse and multifaceted. In Sunni

\footnotetext{
33 This hadith is narrated by Ahmad ibn hanbal in his hadith collection al-Musnad, vol 2, number 381. Read Ahmad ibn Hanbal, Al- Musnad (Cairo: Dar al-Hadith, 1995).

${ }^{34}$ Lembaga Pengkajian \& Pengembangan Islam (LPPI), “Gerbang Marhamah Gerakan Pembangunan Masyarakat Berakhlakul Karimah Kabupaten Cianjur: Rencana Strategis Mewujudkan Masyarakat Cianjur Sugih Mukti Yang Islami” (Cianjur: Lembaga Pengkajian \& Pengembangan Islam, 2002); LPPI, "Perjalanan Gerbang Marhamah (Gerakan Pembangunan Masyarakat Berakhlakul Karimah) Tahap 1 (Pertama) Periode 5 Tahun 1422 H/2001 M - 1436 H/2005 M" (Cianjur: Lembaga Pengkajian \& Pengembangan Islam, 2005).
} 
tradition, for instance, there are four equally orthodox schools of law such as the Hanafi, named after Abu Hanifa (d. 767); the Maliki, named after Malik b. Anas (d. 795); the Shafi'I, named after Shafi'i (d.820); and the Hambali, named after Ahmad b Hanbal (d. 855). 35 The majority of Indonesian Muslims, for instance, are traditionally Sunni of the Shafi'i Mazhab ${ }^{36}$ but there is a broader diversity of Indonesian Islam that includes groups such as the traditionalist Nahdatul Ulama, or the modernist Muhammadiyah and PERSIS.

Regarding Sharia, there are groups within Indonesian Muslims who object the application of it because of the association to the practice of Arabian Muslims. In their view, the practice of sharia in the Arabian Muslims was not necessarily applicable to the Indonesian Muslims. ${ }^{37}$ This group is very critical to forming of sharia that, in their view, is an expression of Arab Muslims rather than Indonesian Muslims. ${ }^{38}$ The substantial characteristic that differentiates Indonesian Muslims to the Arabian Muslims is the fact that Indonesia is a pluralistic society and having a different historical background of the coming of Islam. ${ }^{39}$ Also, many Indonesian Muslims also opposes sharia literal interpretation of criminal law with its primitive punishments such as hand amputation, death penalty, and stoning. 40 These indicate that

35 Gerhard Böwering, Patricia Crone, and Mahan Mirza, The Princeton Encyclopedia of Islamic Political Thought (Princeton University Press, 2013), p. 498 .

${ }^{36}$ Robert W. Hefner, "Religion: Evolving Pluralism", in Indonesia Beyond Subarto: Polity, Economy, Society, Transition, ed. Donald K. Emmerson (New York: M.E. Sharpe, 1999); Kecia Ali, Imam Shafi'i: Scholar and Saint (England: Oneworld Publications, 2011).

37 Martin van Bruinessen, "Ghazwul Fikri or Arabization? Indonesian Muslim Responses to Globalization", in Ken Miichi, Omar Farouk (eds), Southeast Asian Muslims in the Era of Globalization (Hampshire: Palgrave Macmilan, 2015), p. 61

38 See for instance, Abdurrahman Wahid, Pergulatan Negara, Agama, dan Kebudayaan (Jakarta: Desantara, 2001).

${ }^{39}$ Anthony Reid, Southeast Asia in the Age of Commerce, 1450-1680: Volume 2, Expansion and Crisis, Reprint edition (New Haven: Yale University Press, 1995); Robert W. Hefner, Civil Islam: Muslims and Democratization in Indonesia (New York: Princeton University Press, 2000); Robert W. Hefner, "Islam in an Era of Nation-State: Politics and Religious Renewal in Muslim Southeast Asia," in Islam in an Era of Nation-States: Politics and Religious Renewal in Muslim Southeast Asia, ed. Robert W. Hefner and Patricia Horvatich (University of Hawaii Press, 1997), pp. 3-42.

40 See for Instance, Nur Rofi'ah and Imam Nahe'i, Kajian tentang Hukum dan Penghukuman dalam Islam: Konsep Ideal Hudud dan Praktiknya (Jakarta: Komnas Perempuan, 2016). 
sharia is not a fixed and single form of application and indeed open to influence by sociological, cultural, historical, and political contexts.

\section{Diverse Social Group with No Single Group Predominating}

Another factor enables the fitted sharia is because political processes in Cianjur are flexible enough to accommodate and engage different groups. Cianjur is home to some diverse civic associations and political groups, both the Islamists and the nationalists, with no single group predominating. Moreover, Islamic groups are far from unified on this issue. Although Nahdatul Ulama is the major cultural expression of the Muslim people in Cianjur, but it is an organization no bigger and more membership than Persatuan Islam, Muhammadiyah, or Persatuan Umat Islam.

Likewise, Islam-associated parties are divided into several parties that reflect different schools of thought, cultures of religiosity, and political preference. ${ }^{41}$ Although these party have seemingly similar agenda on shariatization in Cianjur, their pragmatic political goals certainly different. They also rely on different mass bases. Partai Bulan Bintang, Partai Keadilan Sejahtera, and Partai Amanat Nasional usually have membership of modernist as well as islamist Muslims with apparent aspiration to implement sharia through political avenues. On the other hand, Partai Kebangkitan Bangsa PPP_Partai Persatuan Pembangunan) have mass bases of traditional muslims which put less emphasis on sharia implementation. Meanwhile, the secularnationalists are also divided into numbers of political parties such as the Golkar Party (Golongan Karya), Democrat Party (Partai Demokrat), Indonesian Democratic Party of Struggle (PDIP-Partai Demokrasi Indonesia Perjuangan), and the fast growing Nasional Demokrat Party (Nasdem - National Democrat Party).

However, during political races, these parties often form coalitions beyond their ideological platforms. For instance, in the 2015 local direct election, there are two political coalitions in which each coalition was formed from nationalist-secular parties and islamist parties. Irvan Rivano Muchtar-Herman Suherman, who later won the election were

\footnotetext{
${ }^{41}$ Zachary Abuza, Political Islam and Violence in Indonesia (New York: Routledge, 2007); Rachel Rinaldo, Mobilizing Piety: Islam and Feminism in Indonesia (Oxford, UK: Oxford University Press, 2013); Robert W Hefner, "Islam and Nation in the Post Suharto Era", in The Politics of Post Subarto Indonesia, ed. Adam Schwarz and Jonathan Paris (New York: Council on Foreign Relations Press, 1999), pp. 40-72.
} 
backed by a secular-nationalist party of Partai Golkar and two islamist parties of Partai Bulan Bintang and Partai Kebangkitan Bangsa. In the opposite side, Suranto-Aldwin Rahadian were supported by five secular nationalist parties of PDI Perjuangan, Hanura, Gerindra, NasDem, and Partai Demokrat and three islamist parties of PAN, PKS, PPP. ${ }^{42}$

Therefore, the political articulations of those Islamist and nationalist groups which are supposedly prone to disagreement on many ideological and strategic issues between and within them in existing arrangements, do not take place or at least do not create much tension or even conflict. This fluid as well as pragmatic approach to ideology is able to contain and even reach compromises upon particular policies and agendas. Here, democracy is to maintain 'the social' as an open space coloured by the persistence of conflict and disagreement, whereby it is impossible to have a single perspective or universal point of view. Throughout conflict and disagreement, different contesting groups could maintain compromise and coalition, although the compromise and contestation did not necessarily become permanent as it is open to change, following the dynamics of local political developments and agenda. ${ }^{43}$ Within this frame, the persistence of sharia-related symbolism in post-Islamists' electoral failure of 2005 could not be understood merely in the frame of politics of inclusion. Rather, the ruling group - mainly the secular nationalists-and the ruled group - the Islamists-following the 2005 election, held a relatively equal position and influence over local politics in Cianjur. Within this mutual influence and exchange of interests, the contesting groups adjusted and adapted their ideologies and strategies to fit with one another.

Moreover, although Islam is the majority religion and religious life is salient, political Islam has not been as strong as Muslim culture in Cianjur. Since the independence of Indonesia in 1945, the Islamist politics was much less influential in Cianjur. Although Cianjur had influential Ulama or any kind of muslim leadership who had reasonable contribution during armed resistance against colonialism in pre-independent Indonesia, none of those Islamist figures became

\footnotetext{
${ }^{42}$ Republika Online, Pilkada Cianjur Tjetjep Mochtar-Dadang Supianto Pasangan PKS-Partai Demokrat, http://www.republika.co.id/Online_detail.asp?id=222054\&kat_id $=23$, accessed on 20 November 2005

${ }^{43}$ Laclau and Mouffe, Hegemony and Socialist Strategy, p. 22
} 
involved in local politics or served as top range bureaucrats in the early period of independent Indonesia. At that time, there were 17 districts in the West Java region, but none of the Ulama gained a position of Head of District. The posts were all served by the proponents of Soekarno's Indonesian National Party (PNI - Partai National Indonesia). Even in the first general election of 1955, Masyumi got fewer votes than the PNI in Cianjur. The story was even worse in the following decades of Suharto's New Order era when Islamist parties lost significant numbers of constituents. This trend continues in the post-Suharto era of 1998 when the Islamist parties were even outside of the big three list parties in Cianjur.

All Islamic-Islamist parties in four consecutive general elections of post-Suharto period (1999, 2004, 2009, and 2014) saw significant declines in popular votes from 39.7 percent in 1999 to 36.2 and 29.2 in 2004 and 2009 respectively, but then slightly increased to 30.3 percent in 2014. Out of the five Islam-based parties, only the PKS had constantly increased their share of votes in the last four elections of post-Suharto. In comparison to the secular-nationalist parties, the total votes of Islam-based parties were much fewer than the nationalist parties such as the Golkar, PDIP, and Demokrat Party in all four elections of post-Suharto. The failure of Islam-based parties had rooted in the first-ever 1955 general election of the republic when the Islam-based parties (the Nahdatul Ulama and the Masyumi) obtained fewer votes than the nationalist of Partai Nasional Indonesia (PNI). Under the New Order of Suharto (1966-1998), Islam-based parties lost significant numbers of constituents, and even worse in post Suharto era when the Islam-based parties (the Islamic and Islamist parties) ${ }^{44}$ where outside of the big three list parties in Cianjur (Partai Golkar, PDIP and Partai Demokrat).

The unconsolidated political Islamism in Cianjur is because Muslims were affiliated with widely diverse social organisations. Although Cianjur's cultural religiosity is predominantly traditional and therefore resembles practices of the Nahdatul Ulama (NU), the

44 The Islamist parties refer to the Crescent and Star Party (PBB-Partai Bulan Bintang) and the United Development Party (PPP_Partai Persatuan Pembangunan) as they have formally stated that Islam is the basic principle of the party, instead of Pancasila. The Islamic parties refer to the Justice and Prosperous Party (PKS-Partai Keadilan Sejahtera), the National Awakening Party (PKB-Partai Kebangkitan Bangsa), and the National Mandate Party (PAN-Partai Amanat Nasional) as they are based on Pancasila as a party principle, although their major constituents are Muslims. 
registered members and the formal branches of the NU are very insignificant in Cianjur. The number is much less than two modernist muslims organizations; Persatuan Islam and Muhammadiyah. It is because the people identified themselves as (culturally) NU, without submitting to the organization and formal structure of the NU, neither linked to its affiliated political parties - PKB and PPP.

The local elites-both the Islamists and secular nationalists- still need to employed symbolism related to shariatization in particular and religious-related issues, in general, to establish Islamic credentials and thus supposedly attract constituency support prior to an election. In other words, the mobilization of sharia-related symbolism does not necessarily relate to promoting Islamic piety and law but is used by some individuals and political groups to provide lucrative 'protection' services for local businesses and neighborhoods. ${ }^{45}$ The adoption of shariatization strategy could have also been a result of heightened political competition among elites in localities, especially to secure political positions. In this regard, the elites who run for candidacy are compelled to compromise with the Islamists in those localities as the Islamists maintained powerful local networks through religious organizations, especially the pesantrens (Islamic boarding schools). From this form of relationship, the majority of sharia-related regulations are enacted in localities with political support from 'secular' executive heads who had no direct-formal and personal affiliation with Islamist parties but rather belonged to the nationalist-secular parties (i.e., the Party of Golkar and PDIP), New Order military, or civilian bureaucracy.

At the provincial level, eight out of 34 provinces had adopted at least one sharia regulation between 1999 and 2009. The Islamist Party of PPP gathered a plurality of votes in one province (Aceh), whereas in the rest provinces the secular nationalist party of the Golkar and the PDIP won either through winning the majority of votes or through a plurality of votes. Here, the term of 'a plurality of votes' refers to a coalition of multi-parties whereas the term 'majority' refers to a single dominant party's vote. Meanwhile, at the district and municipality levels in the same period (1999-2009), among the 54 (out of 497) districts and municipalities, they had adopted at least one shariainspired regulation. The Islam-based party of PAN collected a majority

${ }^{45}$ Robert W. Hefner, "Shari'a Politics and Indonesian Democracy", The Review of Faith \& International Affairs 10, no. 4 (2012), pp. 61-69, 
of votes in two districts, and the Islamist PPP collected a plurality of votes in five districts. In the other districts and municipalities, the Golkar party won the majority in five districts and municipalities and, in a plurality, the other thirty-one districts, whereas the PDIP won a plurality of votes in only eight districts. In those provinces and districts/municipalities, 69.4 per cent of executive heads were previously connected with the New Order military or civilian bureaucracy or the secular Golkar party. ${ }^{46}$

\section{The Secular Function of the Sharia}

The co-existence of shariatization and democratic processes in Cianjur is also related to the fact that sharia has a number of mundane functions in politics, economy, and culture. Regarding politics, the adoption of shariatization have been a result of heightened political competition in the localities, especially to win the local political positions. In this regard, the elites who run for candidacy need to compromise with the Islamists in those localities as the Islamists maintained powerful local networks through religious organizations, especially the pesantrens, traditional Islamic boarding schools. These pesantrens are often led by charismatic teacher and clerics with many faithful followers which give them political leverage. ${ }^{47}$ In other words, sharia-inspired regulation, including the policy of zakat, is not always driven by the religious principle of Islamism but it is also shaped by a political orientation that employ sharia symbolism as a political commodity for use in reinforcing Islamic credentials. ${ }^{48}$ Shariatization in particular and religious-related issues, in general, has been used by local elites as a means to establish Islamic credentials and thus supposedly attract constituency support in the election. Here, Shariatization produced a form of symbolism that can be employed by the contesting groups amidst democratization to win political goals. Thus, the mobilization of sharia-related symbolism does not necessarily relate to promoting Islamic piety and law but is used by some Islamist groups to provide lucrative 'protection' services for local businesses and

\footnotetext{
46 Buehler, "Subnational Islamization through Secular Parties."

${ }^{47}$ For an account of the clerics' role in politic, please refer to a classic work of Clifford Geertz entitled "The Javanese Kijaji: The Changing Role of a Cultural Broker", Comparative Studies in Society and History, vol. 2, No. 2 (January 1960), pp. 228-249.

48 cf. Platzdasch, Islamism in Indonesia: Politics in the Emerging Democracy (Singapore: ISEAS-Yusof Ishak Institute. 2009).
} 
neighborhoods. ${ }^{49}$ As a result, sharia-related regulations are enacted in localities with political support from 'secular' executive heads who has no direct-formal affiliation with Islamist parties but rather belong to the nationalist-secular parties (i.e., Partai Golkar and PDIP), New Order military, or civilian bureaucracy.

There are two arguments related to why the secular-affiliated politicians support and enact many shariatization policies. First, support by the secular-affiliated politicians is possible because institutionalization of political parties is weak and this eventually enforced a running candidate to rely on the role of power brokers to help them win election. Here, the power brokers refer to groups or individuals who are able to mobilize their networks and religious credentials for popular votes in the election. Sharia has provided symbolism that could be used by those brokers to attract public attention and political support among religious elites who maintained networks to the pesantrens. Second, in the high levels of competition in an election, a candidate will not only need to have strong economic capital (money) to fund his or her political campaign, but also cultural capital related to cultural goods and symbols as well as social capital related to powerful acquaintances and networks. ${ }^{50}$

Admittedly, seculars' support for sharia-inspired regulations is not a typical phenomenon of the post-Suharto era. During the Suharto era, especially from the late 1980s to 1990s, Suharto had enacted policies that allowed the establishment of the Sharia-based Bank Mu'amalat. He also approached muslim organizations such as Nahdlatul Ulama and Muhammadiyah as well as allowed the formation of Indonesian muslim intellectual association (ICMI - Ikatan Cendekiawan Muslim Indonesia) in the early 1990a. Suharto also allowed Muslim schoolgirls to wear Muslim dress in schools. ${ }^{51}$ Those policies, however, are not simply intended to support Muslims' political cause, but rather to strengthen the political legitimacy of the regime, at least in the eyes of Muslims, particularly the Ulama.

\footnotetext{
${ }^{49}$ Hefner, "Shari‘a Politics and Indonesian Democracy", p. 62.

${ }^{50}$ Buehler, The Politics of Shari'a, p. 24..

51 Please refer to Robert Hefner's work entitled Civil Islam: Muslims and Democratization in Indonesia (Princeton: Princeton University Press, 2000) which provides an insight into the changing nature of political alliances in the final years of the Suharto era when he tried to reach out Muslims for political support.
} 
Also, symbolism of Sharia has been reflected in Islamic philanthropy, not only amongst Islamists but also secular-nationalists. In the late 1990s, Indonesian economy was in collapse, as reflected by the Gross Domestic Product dropping 15 percent in 1998 from an annual average growth of about 7 percent in the seven years since $1990 .{ }^{52}$ It was exacerbated by the fact that, since the devastating economic crisis of 1998, poverty and unemployment rates dramatically increased. The number of poor people more than doubled in a few years from about 22 million in 1996 to 49.5 million in 1999. In many areas of the world, very impoverished people are also very religious. One could say that poverty makes it more likely that people turn to religion-and perhaps more fundamental versions of it-because it can provide some security and meaning to chaotic lives. ${ }^{53}$ The Gallup survey indicated religiosity has been highest in the world's poorest nations, and there is a tendency that the higher the income, the lower the importance of religion in people's life. ${ }^{4}$ Thus, the cure of poverty from religious values is a strategic combinantion. In Islam, zakah (obligatory alms) potentially plays important role.

Zakah, or zakat in Indonesian pronunciation, is part of the five pillars of Islam, and in Pakistan ${ }^{55}$ and Bahrain, ${ }^{56}$ for instance, it has reduced income inequality. In Cianjur, it was observed that the issuance of the Zakat policy is not only of the interest of the Islamists but also the secular nationalists. Indeed, the policy was implemented under the nationalist-led Executive Head (2006-2011). Through the Zakat policy the nationalists shored up their power and maintained religious channels to increase their electability. The funds collected

\footnotetext{
52 Jonathan Temple, "Growing into Trouble: Indonesia After 1966," CEPR Discussion Paper (C.E.P.R. Discussion Papers, 2001), http://ideas.repec.org/p/cpr/ceprdp/2932.html; Thomas B. Pepinsky, Economic Crises and the Breakdown of Authoritarian Regimes: Indonesia and Malaysia in Comparative Perspective (Cambridge, UK: Cambridge University Press, 2009).

${ }^{53}$ H. Burke, "Ideology and the material culture of life and death", in M. Hall and S.W. Silliman (eds), Historical Archeology (Oxford: Blackwell Publishing), pp. 128-146.

54 Steve Crabtree, "Religiosity Highest in World's Poorest Nations: United States Is among the Rich Countries That Buck the Trend," August 31, 2010, http://www.gallup.com/poll/142727/religiosity-highest-world-poorest-nations.aspx.

55 Geoffrey A Jehle, "Zakat and Inquality: Some Evidence Form Pakistan", Review of Income and Wealth Series 40, Number 2 (June 1994): pp. 205-16.

${ }^{56}$ Hisyam Abdelbaki, "The Impact of Zakat on Poverty and Income Inequality in Bahrain”, Review of Integrative Business \& Economics 2(1) (2013): pp. 133-54.
} 
from the zakat are expected to support economic activities of small businesses as well as to provide survival assistance for needy people and other designated groups of recipients, ${ }^{57}$ according to classical Islamic law..$^{58}$ Regardless the under performance of zakah management in Cianjur, ${ }^{59}$ and the success rate of poverty eradication is still low, the policy itself has served positive political image building for secularnationalists politicians in Cianjur.

Last but not least, the emergence of sharia-related symbolism is also associated with a collection of principle values related to culture and custom. ${ }^{60}$ In Indonesian society, it is almost impossible to separate culture and custom from religion. ${ }^{61}$ In this regard, there are many local values of the people that are compatible and associated to the teaching of Islam and eventually have been constructed as synonymous with the adat (local customs, social habits, or practice). The process of mixture or acculturation of Islam and the adat has been taking place since Islam started to take root in Indonesia in around the fourteenth century. ${ }^{62}$ The 'nick name' of Cianjur as a Kota Santri (City of Pious Muslims) has indicated that the adat and symbolism of Islam have, for

${ }^{57}$ According to the Quran (9:60), there are eight designated groups of recipients of zakat, namely the poor (al-fuqara), the needy (al-masaakin), the collectors of zakat, newly converts, (freeing) slaves, those overburdened with debts, workers in God's way ( $f i$ sabilillab), and wayfarers (ibn-sabil)

${ }^{58}$ In Indonesia, the management of zakah (both collection and distribution) has been regulated through the Law No. 38 Year 1999 and amended by Law No. 23 Year 2011. In respect of this, management of the zakat is run by both the semi-state body of the Alms-giving Body (BAZ-Badan Amil Zakat) and the Local Government, under the Office of Social Welfare (Kesejahteraan Rakyat). The BAZ would allocate funds to support small businesses or the so-called informal sector of the economy.

${ }^{59}$ See for instance, annual report from Cianjur Bureau of Statiscic (BPS - Biro Pusat Statistik), from 2008 to 2017 which shows that the target of zakah collection could not be met. Biro Pusat Statistik Cianjur, Kabupaten Cianjur dalam Angka 2015 (Cianjur: Biro Pusat Statistik Cianjur, 2015), pp. 44-49.

${ }^{60}$ Arskal Salim, Challenging the Secular State the Islamization of Law in Modern Indonesia (Honolulu: University of Hawaii Press, 2008), pp. 12-15.

${ }^{61}$ An outdated yet widely cited anthropological account on the relationship between Islam and culture in Java is Clifford Geertz's The Religion of Java (Chicago: Chicago University Press, 1960). Similar account, but in Sumatera is provided by Taufik Abdullah's article entitled "Adat and Islam: An Examination of Conflict in Minangkabau”, Indonesia, no. 2 (Oct., 1966), pp. 1-24

${ }^{62}$ Merle Ricklefs, A History of Modern Indonesia since 1200 C (Hampshire: Palgrave, 2001) third edition, pp. 3-6. 
a long time, blended. This local adat helped to aid non-Muslim groups to accept the symbolism of sharia in public. Mr. Ketut, a leader of Cianjur Hindu community, stated "All religions are promoting akblaq al-karimah (good behaviors). It is just simply adopted from Arabic, which means thoughtfulness, politeness, and morality. So, we could accept it."

Therefore, interpretation and forms of application of sharia are not merely determined by the Islamic orthodox doctrines and teachings. It is well observed in the District of Cianjur, for instance, that the shariarelated regulation is remarkably adaptive and accommodative. Or more precisely, its form and symbol are subject to its conformity to the Constitution of Indonesia, which is non-theological. ${ }^{63} \mathrm{It}$ is thus a moderate form of sharia that is developed in response to heightened suspicions and resistance from the local, national and global critics of what they saw as the Islamization of Indonesia.

The emergence of the symbolism of Islam, including those related to sharia, is rooted in the social composition of Cianjur that has maintained a strong cultural association with Islam. The wearing of jilbab (women head scarfs), for instance, has not merely associated with Islam but also the adat. Since it has become a custom, certain nonMuslims willingly wear it. Ms. Musiyem, a Cianjur person who happens to be a Catholic, wears head scarf in her daily activities, including in her work as a teacher at a public elementary school. She reveals that that she and her family members are familiar with the head veil and other Islam-related symbols. Musiyem states that she has grown up in the so-called "Pancasila Family" - the term often used in Indonesia to denote a family, mostly an extended family, where the members belonged to different religious beliefs. ${ }^{64}$ Her life experience has thus enabled her to develop a personal capacity to adjust herself to the wearing of a head scarf as some of her family members are Muslims and wearing them.

Musiyem's experience of wearing a Muslim Women's head veil can also be seen as a proof that human being are social animals and have a strong desire to conform to those around them. As Musiyem has

${ }^{63}$ Bupati Cianjur, "Apa Dan Bagaimana Pelaksanaan Syari'at; LPPI, "Gerbang Marhamah Gerakan Pembangunan Masyarakat Berakhlakul Karimah; LPPI, "Format Dasar Pelaksanaan Syariat Islam.

${ }^{64}$ Suhadi, "I Come from a Pancasila Family": A Discursive Study on Muslim-Christian Identity Transformation in Indonesian Post-Reformasi Era (Zürich: LIT Verlag, 2014). 
grown in the "Pancasila Family," which allowed her to be intensely exposed to a Muslim dress code, she is then familiar with this and adopts it. Therefore, it is important to note that in Indonesian society it is almost impossible to separate culture and custom from religion. ${ }^{65}$ Disregarding the part played by culture and custom in the development of shariatization will lead to misunderstanding the whole picture of the resurgence of sharia-related regulations.

\section{Conclusion}

The instigation of the sharia-related regulations in Cianjur is another case that challenge the incompatibility argument to 'fitting through' relationship between Islam and democracy. In the frame of incompatibility argument, the development of democracy would undermine Islamism, including shariatization, and vice versa. What unfolded in Cianjur, however, the resurgence of the sharia-inspired regulations is a product of, and thus fitting through, democratic political processes that engaged together with the elected legislative body and the executive office as well as various social groups at the local. this is possible because sharia has discursive elements that enable it to be fitted or repackaged amidst negotiation between different civic groups. The fact that Cianjur, as elsewhere in Indonesia, is home to Islamic groups as well as secular-nationalists, which compels them to negotiate political aspirations. As the so-called sharia has secular functions related to political alliance, economic interests, and local custom and values, reaching acceptable platform is not beyond realization.]

\section{References}

\section{Books and Articles}

Abdelbaki, Hisyam. "The Impact of Zakat on Poverty and Income Inequality in Bahrain." Review of Integrative Business \& Economics 2(1) (2013): pp. 133-54.

Abuza, Zachary. Political Islam and Violence in Indonesia. New York: Routledge, 2007.

\footnotetext{
${ }^{65}$ A good article review from historical perspective on the matter is exposed by Martin van Bruinessen in his work entitled "Global and local in Indonesian Islam", Southeast Asian Studies, vol. 37, no. 2 (1999), pp. 46-63.
} 
Ali, Kecia. Imam Shafi'i: Scholar and Saint. England: Oneworld Publications, 2011.

Asad, Talal. The Idea of an Anthropology of Islam. Occasional Papers Series/Center for Contemporary Arab Studies, Georgetown University. Washington, D.C: Center for Contemporary Arab Studies, Georgetown University, 1986.

Azca, Muhammad Najib. "After Jihad: A Biographical Approach to Passionate Politics in Indonesia." University of Amsterdam, 2011.

Böwering, Gerhard, Patricia Crone, and Mahan Mirza. The Princeton Encyclopedia of Islamic Political Thought. Princeton University Press, 2013.

Buehler, Michael. "Subnational Islamization through Secular Parties: Comparing Shari'a Politics in Two Indonesian Provinces." Comparative Politics 46, no. 1 (October 1, 2013): 63-82. https://doi.org/10.5129/001041513807709347.

Bupati Cianjur. “Apa Dan Bagaimana Pelaksanaan Syari'at Islam Di Kabupaten Cianjur: Bahan Penyuluhan Dan Sosialisasi Bagi Para Petugas Akhlaqul Karimah (PAK) Di Kabupaten Cianjur," 2002.

Bush, Robin. "Regional Sharia Regulations in Indonesia: Anomaly of Symptom?." In Expressing Islam: Religious Life and Politics in Indonesia, 174-91, 2008.

Crabtree, Steve. "Religiosity Highest in World's Poorest Nations: United States Is among the Rich Countries That Buck the Trend," August 31, 2010. http://www.gallup.com/poll/142727 / religiosity-highest-world-poorest-nations.aspx.

Dahl, Robert Alan. Polyarchy: Participation and Opposition. USA: Yale University Press, 1971.

Freedom House. "Indonesia." Freedom in the World, 2013. http://www.freedomhouse.org/report/freedomworld/2013/indonesia.

Fukuyama, Francis. The End of History and the Last Man. New York: Simon and Schuster, 1989. 
- "The West Has Won." The Guardian, October 10, 2001, sec. World news. http://www.theguardian.com/world/2001/oct/11 /afghanistan.terrorism 30 .

Geertz, Clifford. The Religion of Java. London: University of Chicago Press, 1960.

Habermas, Jürgen. The Theory of Communicative Action: Reason and the Rationalization of Society. USA: Beacon Press, 1984.

Hale, William, and Ergun Ozbudun. Islamism, Democracy and Liberalism in Turkey: The Case of the AKP. New York: Routledge, 2009.

Hasan, Noorhaidi. Laskar Jihad: Islam, Militancy, and the Quest for Identity in Post-New Order Indonesia. Ithaca, N.Y.: Southeast Asia Program Publications, Southeast Asia Program, Cornell University, 2006.

Hasani, Ismail. Radikalisme Agama Di Jabodetabek \& Jawa Barat: Implikasi Terbadap Jaminan Kebebasan Beragama/berkeyakinan. Jakarta, Indonesia: Publikasi SETARA Institute, 2011.

Hefner, Robert W. "Islam and Nation in the Post Suharto Era." In The Politics of Post Subarto Indonesia, edited by Adam Schwarz and Jonathan Paris. New York: Council on Foreign Relations Press, 1999.

Hefner, Robert W. Civil Islam: Muslims and Democratization in Indonesia. New York: Princeton University Press, 2000.

-. "Islam in an Era of Nation-State: Politics and Religious Renewal in Muslim Southeast Asia." In Islam in an Era of NationStates: Politics and Religious Renewal in Muslim Southeast Asia, edited by Robert W. Hefner and Patricia Horvatich. University of Hawaii Press, 1997.

---------. "Religion: Evolving Pluralism." In Indonesia Beyond Subarto: Polity, Economy, Society, Transition, edited by Donald K. Emmerson. New York: M.E. Sharpe, 1999.

--------. "Shari'a Politics and Indonesian Democracy." The Review of Faith \& International Affairs 10, no. 4 (2012): 61-69. https://doi.org/10.1080/15570274.2012.739889.

Hilmy, Masdar. Islamism and Democracy in Indonesia: Piety and Pragmatism. Singapore: Institute of Southeast Asian Studies, 2010. 
Huntington, Samuel P. The Clash of Civilizations and the Remaking of World Order. Simon \& Schuster pbk. ed. New York: Simon \& Schuster Paperbacks, 1993.

-. The Third Wave: Democratization in the Late 20th Century. USA: University of Oklahoma Press, 1991.

Jehle, Geoffrey A. "Zakat and Inquality: Some Evidence Form Pakistan." Review of Income and Wealth Series 40, Number 2 (June 1994): pp. 205-16.

Katz, Richard S., and Peter Mair. "Changing Models of Party Organization and Party Democracy The Emergence of the Cartel Party." Party Politics 1, no. 1 (January 1, 1995): 5-28. https://doi.org/10.1177/1354068895001001001.

Laclau, Ernesto. "Identity and Hegemony: The Role of Universality in the Constitution of Political Logics." In Contingency, Hegemony, Universality: Contemporary Dialogues on the Left, edited by Judith Butler, Ernesto Laclau, and Slavoj Žižek. Verso, 2000.

. On Populist Reason. Verso, 2005.

-. "Politics and the Limits of Modernity." Social Text, no. 21 (January 1, 1989): 63-82. https://doi.org/10.2307/827809.

-----. "Power and Representation." In Politics, Theory, and Contemporary Culture, edited by Mark Poster, 277-96. USA: Columbia University Press, 1993.

Laclau, Ernesto, and Chantal Mouffe. Hegemony and Socialist Strategy: Towards a Radical Democratic Politics. Verso, 2001.

Lewis, Bernard. The Crisis of Islam: Holy War and Unholy Terror. New York: Random House Trade Paperbacks, 2004.

LPPI. "Format Dasar Pelaksanaan Syariat Islam Di Kabupaten Cianjur." Lembaga Pengkajian \& Pengembangan Islam Kabupaten Cianjur, 2001.

-. "Gerbang Marhamah Gerakan Pembangunan Masyarakat Berakhlakul Karimah Kabupaten Cianjur: Rencana Strategis Mewujudkan Masyarakat Cianjur Sugih Mukti Yang Islami." Lembaga Pengkajian \& Pengembangan Islam, 2002.

. "Perjalanan Gerbang Marhamah (Gerakan Pembangunan Masyarakat Berakhlakul Karimah) Tahap 1 (Pertama) Periode 5 
Tahun 1422 H/2001 M - 1436 H/2005 M.” Lembaga Pengkajian \& Pengembangan Islam, 2005.

Mahbubani, Kishore. “Indonesia’s Democratic Miracle.” the Guardian, September 19, 2008. http://www.theguardian.com/commentisfree/2008/sep/19/indonesia.terrorism.

Mouffe, Chantal. "Deliberative Democracy or Agonistic Pluralism?" Social Research 66, no. 3 (October 1, 1999): 745-58.

------. The Return of the Political. Phronesis. London; New York: Verso, 1993.

An-Na im, Abdullahi Ahmed. Islam and the Secular State: Negotiating the Future of Shari ${ }^{a}$. Cambridge, MA: Harvard University Press, 2010.

Norval, Aletta J. Aversive Democracy: Inheritance and Originality in the Democratic Tradition. Cambridge, UK: Cambridge University Press, 2007.

Pepinsky, Thomas B. Economic Crises and the Breakdown of Authoritarian Regimes: Indonesia and Malaysia in Comparative Perspective. Cambridge, UK: Cambridge University Press, 2009.

Platzdasch, Bernhard. Islamism in Indonesia: Politics in the Emerging Democracy. Singapore: Institute of Southeast Asian Studies, 2009.

Reid, Anthony. Southeast Asia in the Age of Commerce, 1450-1680: Volume 2, Expansion and Crisis. Reprint edition. New Haven: Yale University Press, 1995.

Rinaldo, Rachel. Mobilizing Piety: Islam and Feminism in Indonesia. Oxford, UK: Oxford University Press, 2013.

Rose, R. "Democratic and Undemocratic States." In Democratization, edited by Christian Haerpfer, Patrick Bernhagen, Ronald F. Inglehart, and Christian Welzel. Oxford: OUP Oxford, 2009.

Said, Edward W. Orientalism: Western Conceptions of the Orient. USA: Penguin Books Limited, 2001.

Salim, Arskal. Challenging the Secular State the Islamization of Law in Modern Indonesia. Honolulu: University of Hawaii Press, 2008.

--------. "The Islamisation of Regional Regulations and Its Impact on Good Governance in Contemporary Indonesia." edited by Tim 
Lindsey, Helen Pausacker, Religion, Law and Intolerance in Indonesia. Abingdon and New York: Routledge, 2016.

Schumpeter, Joseph A. Capitalism, Socialism, and Democracy. Radford, VA : Wilder Publications Limited, 2012.

Schwarz, Adam. A Nation in Waiting: Indonesia's Search for Stability. Australia. Boulder, Colo.: Westview Press, 2000.

Slater, Dan. Ordering Power: Contentious Politics and Authoritarian Leviathans in Southeast Asia. Cambridge: Cambridge University Press, 2010.

Suhadi. "I Come from a Pancasila Family": A Discursive Study on MuslimChristian Identity Transformation in Indonesian Post-Reformasi Era. Zürich: LIT Verlag, 2014.

Temple, Jonathan. "Growing into Trouble: Indonesia After 1966." CEPR Discussion Paper. C.E.P.R. Discussion Papers, 2001. http://ideas.repec.org/p/cpr/ceprdp/2932.html. 